\title{
Ammonium and non-sea salt sulfate in the EPICA ice cores as indicator of biological activity in the Southern Ocean
}

\author{
Patrik Kaufmann ${ }^{\text {a,b }}$, Felix Fundel ${ }^{\text {c,1 }}$, Hubertus Fischer ${ }^{\text {a,b,c,* }}$, Matthias Bigler ${ }^{\text {a,d }}$, Urs Ruth ${ }^{c}$, \\ Roberto Udisti ${ }^{\mathrm{e}}$, Margareta Hansson ${ }^{\mathrm{e}}$, Martine de Angelis ${ }^{\mathrm{f}}$, Carlo Barbante ${ }^{\mathrm{g}}$, Eric W. Wolff ${ }^{\mathrm{h}, \mathrm{i}}$, \\ Manuel Hutterli ${ }^{\mathrm{j}}$, Dietmar Wagenbach ${ }^{\mathrm{k}}$ \\ ${ }^{a}$ Climate and Environmental Physics, University of Bern, Sidlerstrasse 5, 3012 Bern, Switzerland \\ ${ }^{\mathrm{b}}$ Oeschger Centre for Climate Change Research, University of Bern, 3012 Bern, Switzerland \\ ${ }^{\mathrm{c}}$ Alfred Wegener Institute for Polar and Marine Research, Columbusstrasse, 27568 Bremerhaven, Germany \\ d Centre for Ice and Climate, Niels Bohr Institute, University of Copenhagen, Juliane Maries Vej 30, 2100 Copenhagen Ø, Denmark \\ ${ }^{\mathrm{e}}$ Department of Chemistry, University of Florence, Via della Lastruccia 3, 50019 Sesto Fiorentino Florence, Italy \\ ${ }^{\mathrm{f}}$ Department of Physical Geography and Quaternary Geology, Stockholm University, 10691 Stockholm, Sweden \\ ${ }^{\mathrm{g}}$ Laboratoire de Glaciologie et Gèophysique de l'Environnement, 38402 St Martin d'Hères cedex, France \\ ${ }^{\mathrm{h}}$ Institute for the Dynamics of Environmental Processes - CNR, 30123 Venice, Italy \\ ${ }^{\mathrm{i}}$ Department of Environmental Sciences, University of Venice, 30123 Venice, Italy \\ ${ }^{\mathrm{j}}$ British Antarctic Survey, High Cross, Madingley Road, Cambridge CB3 OET, UK \\ ${ }^{\mathrm{k}}$ Institut für Umweltphysik, University of Heidelberg, INF 229, 69120 Heidelberg, Germany
}

\section{A R T I C L E I N F O}

\section{Article history:}

Received 8 February 2009

Received in revised form

29 October 2009

Accepted 1 November 2009

\begin{abstract}
A B S T R A C T
Sulfate $\left(\mathrm{SO}_{4}^{2-}\right)$ and ammonium $\left(\mathrm{NH}_{4}^{+}\right)$flux records over the last 150,000 years from both Antarctic EPICA ice cores (European Project for Ice Coring in Antarctica) are presented. The ice core record from Dome $\mathrm{C}$ is influenced by the Indian sector of the Southern Ocean (SO), whereas Dronning Maud Land is facing the Atlantic sector. Generally, they reflect the past atmospheric aerosol load and, thus, potentially reveal the fingerprint of marine biogenic sources from the SO. The most important feature of both, the nssSO $\mathrm{SO}_{4}^{2-}$ as well as $\mathrm{NH}_{4}^{+}$flux records, is the absence of any significant glacial cycles, in contrary to the distinct transitions for mineral dust and sea salt aerosol over the last 150,000 years. This finding challenges the iron fertilization hypothesis on long time scales, as the significant changes in dust, e.g. from the last glacial maximum toward the Holocene have neither an impact on $\mathrm{nsSSO}_{4}^{2-}$ nor on $\mathrm{NH}_{4}^{+}$fluxes found in interior Antarctica. The inter-site correlation of both species is weak, $r^{2}=0.42$ for the nssSO2- flux and $r^{2}=0.12$ for the $\mathrm{NH}_{4}^{+}$flux respectively, emphasizing the local source characteristics of biogenic aerosol from the SO. Millennial variability in $\mathrm{NH}_{4}^{+}$and nssSO${ }_{4}^{--}$is within the uncertainty of our flux estimates. Correlation with mineral dust and sea ice derived sodium shows only a very weak influence of dust deposition on those insignificant changes in nssSO ${ }_{4}^{-}$flux for the Atlantic sector of the Southern Ocean, but also small transport changes or terrigeneous sulfate contributions may contribute to those variations at EDML.
\end{abstract}

(c) 2009 Elsevier Ltd. All rights reserved.

\section{Introduction}

The Southern Ocean (SO) is a key player in the global carbon cycle (Kohfeld et al., 2005; Fischer et al., 2010 and references therein). The iron fertilization hypothesis introduced by Martin et al. (1990)

\footnotetext{
* Corresponding author at: University of Bern, Sidlerstrasse 5, CH-3012 Bern, Switzerland. Tel.: +4131631 8503; fax: +41316318742.

E-mail address: hubertus.fischer@climate.unibe.ch (H. Fischer).

URL: http://www.climate.unibe.ch

1 Present address: Federal Office of Meteorology and Climatology, MeteoSwiss, 8044 Zürich, Switzerland.
}

assumes an enhanced marine productivity and, thus, carbon drawdown with increasing iron supply by the input of aeolian dust during the glacial. Although there are uncertainties concerning the amount of soluble, and biologically available iron in aeolian dust (estimates from $2 \%$ up to $90 \%$ exist, Watson et al., 2000; Edwards and Sedwick, 2001), this effect is most efficient in regions of high macronutrient concentrations but low productivity due to a limitation in iron such as the SO. Recent model and ice core studies attribute a drawdown of 4-45 ppmv of atmospheric $\mathrm{CO}_{2}$ to the iron fertilization effect (Bopp et al., 2003; Ridgwell, 2003; Köhler et al., 2005; Gaspari et al., 2006; Parekh et al., 2008). Based on ice core records of $\mathrm{CO}_{2}$ and dust over the last 60,000 years, Röthlisberger et al. (2004) and Fischer et al. 
(2010) were able to estimate the limit of the effect of iron fertilization to approximately 10-20 ppmv.

Over the last decades great effort has been put into identifying a proxy for the biogenic activity of the SO from Antarctic ice cores and aerosol samples (e.g. Berresheim, 1987; Legrand et al., 1991; Davis et al., 1998; Legrand and Pasteur, 1998; Minikin et al., 1998; Cosme et al., 2005; Preunkert et al., 2007). Of this, marine biogenic sulfur species (non-sea salt sulfate (nssSO ${ }_{4}^{2-}$ ) and methanesulfonate acid (MSA)) represent the most studied atmospheric tracers. Sulfate isotope records from ice cores could potentially provide additional information on biological activity, but up to now, only few data are available and their temporal changes are interpreted as reflection of the major atmospheric oxidation pathway rather than changes in the source (Alexander et al., 2003). Taking the changes in oxidation into account their findings are in agreement with model results from Cosme et al. (2005), where it was shown that at least $90 \%$ of all sulfate transported towards Antarctica is from marine biogenic production in the surrounding oceans. More precisely they are located in the region between 58 and $66^{\circ} \mathrm{S}$ (Minikin et al., 1998; Preunkert et al., 2007), thus, mostly south of the Antarctic Polar Front at the northern sea ice edge.

Compared to coastal Antarctic sites, where ice core records mainly reflect local marine aerosol production, inland sites are representative of a relatively larger source area (Reijmer et al., 2002) which coincides with regions of enhanced marine biogenic activity (Cosme et al., 2005). Blooms of certain phytoplankton groups such as dinoflagellates and coccolithophorides as well as Phaeocystis, which are very abundant in the SO, produce, e.g. dimethyl-sulfoniopropionate (DMSP) the precursor of dimethylsulfide (DMS). The latter is partly emitted into the atmosphere, mainly during austral summer (Curran and Jones, 2000) and ultimately oxidized in the marine boundary layer (MBL) to $\mathrm{nsSOO}_{4}^{2-}$ and MSA (Davis et al., 1998; Preunkert et al., 2008). Although the varying ratio of MSA to nssSO ${ }_{4}^{-}$is not known precisely, the main product from oxidation of DMS is always $\mathrm{nsSO}_{4}^{2-}$ (Legrand and Pasteur, 1998).

Ammonia $\left(\mathrm{NH}_{3}\right)$ and its form in the aerosol phase ammonium $\left(\mathrm{NH}_{4}^{+}\right)$may potentially represent additional proxies for SO biological productivity not restricted to sulfur producing phytoplankton groups and would reflect the entire biomass produced in the SO. However, up to now only a few ice core studies (e.g. Legrand et al., 1999) have been carried out on $\mathrm{NH}_{4}^{+}$, mostly due to the challenging analysis of $\mathrm{NH}_{4}^{+}$as it is easily contaminated during sampling, storage or analysis.

In the off-shore regions of the ocean, $\mathrm{NH}_{4}^{+}$mainly originates from biological decomposition of organic matter, but there is a highly variable contribution by zooplankton as well (Johnson et al., 2007 and references therein). Reduced nitrogen plays also an important role as nutrient for many phytoplankton species. Moreover, $\mathrm{NH}_{4}^{+}$is the major neutralizer of sulfuric acid and an important pH-regulator of the MBL aerosol (Bouwman et al., 1997). As such $\mathrm{NH}_{4}^{+}$and sulfate aerosol concentrations in the atmosphere are partly linked with each other. The processes within the ocean surface layer and the interaction with the MBL where $\mathrm{NH}_{3}$ and $\mathrm{NH}_{4}^{+}$ are involved, are very complex and dependent on parameters such as temperature, sea water $\mathrm{pH}$ and wind stress. Recently, Johnson and Bell (2008) developed a co-emission concept, where they suggest an interaction mechanism between $\mathrm{nsSSO}_{4}^{2-}$ and $\mathrm{NH}_{4}^{+}$in the MBL. This system is mainly driven by the acidity of the DMSP oxidation products (mainly sulfuric acid) that controls the bidirectional $\mathrm{NH}_{3}$ flux from the ocean surface towards neutralization. The equilibrium of this process is depending on the sea surface temperature and, hence, at first order on latitude. The nssSO ${ }_{4}^{2-}$ is mainly neutralized by the formation of ammoniumsulfate aerosol, but the intermediate ammoniumbisulfate also exists. The model results by Johnson and Bell (2008) on the molar $\mathrm{NH}_{4}^{+} / \mathrm{SO}_{4}^{2-}$ ratio $\left(R_{\mathrm{NS}}\right)$ are within the range of measurements, e.g. by Norman and Leck $(2005)\left(R_{\mathrm{NS}} \approx 0.3\right)$, Virkkula et al. $(2006)\left(R_{\mathrm{NS}} \approx 0.3\right)$ and Ooki et al. (2007) $\left(R_{\mathrm{NS}} \approx 0.4\right)$, indicating only a partial neutralization in the remote SO far from continental $\mathrm{NH}_{3}$ sources. On a transect study on the Atlantic ocean O'Dowd et al. (1997) found that the $\mathrm{R}_{\mathrm{NS}}$ of the accumulation mode aerosol in the MBL versus latitude indicates neutralization of $\mathrm{nsSSO}_{4}^{2-}\left(R_{\mathrm{NS}}=1-2\right)$ as far south as the Antarctic convergence zone $\left(\mathrm{ACZ}, \sim 60^{\circ} \mathrm{S}\right)$. Further south the ratio declines towards lower values $\left(R_{\mathrm{NS}}=0.1-0.4\right)$.

Physical conditions of the ocean surface strongly influence the emission of DMS during algal blooms (Andreae et al., 2003) and subsequently the production of sulfur aerosol and the flux of $\mathrm{NH}_{3}$ (Johnson and Bell, 2008) out of the ocean surface. Iron fertilization experiments showed that diatoms, which only produce low amounts of DMSP, are outgrowing other phytoplankton species when nutrient supply is increased (Martin et al., 1989; Coale et al., 1996; Boyd et al., 2000; Riseman and DiTullio, 2004). Accordingly, although $\mathrm{NH}_{3}$ is principally derived from the overall biomass in the SO, its release to the atmosphere is not independent of marine biogenic sulfur aerosol production which provides the acidic aerosol that partly drives the $\mathrm{NH}_{3}$ flux out of the ocean. Note, however, that despite all those limitations, the season of increased biogenic production in the SO is also the interval of strongly increased biogenic nssSO ${ }_{4}^{-}, \mathrm{NH}_{4}^{+}$and methane sulphonate concentrations in coastal Antarctic aerosol records (Legrand and Pasteur, 1998; Minikin et al., 1998).

In this study, both records of $\mathrm{nsSO}_{4}^{2-}$ and $\mathrm{NH}_{4}^{+}$from the two EPICA (European Project for Ice Coring in Antarctica) ice cores from Dome C (EDC) and Dronning Maud Land (EDML) are presented, covering the time period of the last 150,000 years (EPICA community members, 2004; EPICA community members, 2006). We present the first reliable continuous long-term $\mathrm{NH}_{4}^{+}$records from Antarctica as another more integrative aerosol indicator of the biological activity in the SO, together with the marine biogenic sulfur species $\mathrm{SO}_{4}^{2-}$ record from EDML and the previously published sulfate record from EDC (Wolff et al., 2006).

MSA is subject to postdepositional loss from the snow pack in low accumulation areas (Weller et al., 2004), excluding it as biological productivity proxy in the interior of Antarctica. However, $\mathrm{SO}_{4}^{2-}$ and $\mathrm{NH}_{4}^{+}$are fully preserved in the snow pack after deposition (Silvente and Legrand, 1993). Accordingly, the $\mathrm{SO}_{4}^{2-}$ and $\mathrm{NH}_{4}^{+}$ records from the two EPICA ice cores are in principle able to preserve even rapid climate changes or short-term variability over the last 150,000 years in biogenic aerosol concentrations in the SO region properly. They may provide continuous records related to marine biogenic sulfur and reduced nitrogen emission to the SO atmosphere. Accordingly, they have the potential to reveal whether the marine biosphere underwent significant changes over the last 150,000 year and how this differs in the Indian Ocean and the Atlantic sector of the SO. Ultimately, they may shed light on the importance of the SO biosphere productivity for the observed low atmospheric $\mathrm{CO}_{2}$ concentrations in cold climate periods (Siegenthaler et al., 2005).

\section{Methods}

The ice cores from the two EPICA drill sites provide the data basis for this study: the EDML core from the high plateau of Dronning Maud Land [ $75^{\circ} 00^{\prime} \mathrm{S}, 00^{\circ} 04^{\prime} \mathrm{E}, 2892 \mathrm{~m}$ a.s.l.] facing the Atlantic sector of the SO and the EDC core from Dome Concordia [ $75^{\circ} 06^{\prime} \mathrm{S}, 123^{\circ} 21^{\prime} \mathrm{E}, 3233 \mathrm{~m}$ a.s.l.], with the Indian sector of the SO as main source of deposited aerosol (Reijmer et al., 2002). In contrast to EDC, which is located on a dome, EDML is located on a ridge with a horizontal surface velocity of approximately $1 \mathrm{~m}$ per year 
(Huybrechts et al., 2007). Due to that, the oldest dated ice of 150,000 years BP at $2415.7 \mathrm{~m}$ depth (Ruth et al., 2007) has been initially deposited $160 \mathrm{~km}$ upstream.

In this publication, we present the first continuous $\mathrm{NH}_{4}^{+}$records from Antarctica spanning the last 150,000 years and also, the so far unpublished continuous EDML $\mathrm{SO}_{4}^{2-}$ record, the only long-term $\mathrm{SO}_{4}^{2-}$ record from the Atlantic sector. Other chemistry data of the EDC ice core have already been published for the last 740,000 years $\left(\mathrm{SO}_{4}^{2-}, \mathrm{Na}^{+}\right.$and $\mathrm{Ca}^{2+}$, Wolff et al., 2006) and for the EDML core for the last 150,000 years $\left(\mathrm{Na}^{+}\right.$and $\mathrm{Ca}^{2+}$, Fischer et al., 2007a). The ions were measured either by continuous flow analysis (CFA, Kaufmann et al., 2008) for $\mathrm{NH}_{4}^{+}$, and $\mathrm{Ca}^{2+}$ or ion chromatography (IC, e.g. Littot et al., 2002) for $\mathrm{Na}^{+}$and $\mathrm{SO}_{4}^{2-}$. The continuous flow setup also provided the samples for IC by filling melted sections into polystyrene containers, in parallel to the regular CFA measurements. Using this melting technique only the inner part of the ice core was taken for analysis, avoiding any surface contamination. Immediately after filling, the discrete samples were refrozen and melted shortly before IC measurements. Despite these precautions, IC measurements of $\mathrm{NH}_{4}^{+}$were not usable, due to high contamination of the melted samples by the lab atmosphere during analysis. The CFA setup, however, avoids contact with the air prior to detection of $\mathrm{NH}_{4}^{+}$and, thus, is a well-established technique to provide highprecision $\mathrm{NH}_{4}^{+}$data from low concentration Antarctic records.

The error of all ion concentrations is in general below 10\%. For sulfate the relative concentration error of the analysis is below 5\% (Göktas et al., 2002) and for ammonium the error is below $10 \%$ (Röthlisberger et al., 2000). The EDC concentration measurement of $\mathrm{NH}_{4}^{+}$in the period from 0 to 12,000 years BP is subject to a slightly larger error due to problems with the analysis setup. However this does not represent a major constraint for the interpretation of the $\mathrm{EDC} \mathrm{NH}_{4}^{+}$dataset. The EDML $\mathrm{SO}_{4}^{2-}$ record from coarse resolution samples (meter-means) revealed a constant systematic offset of $-20 \mathrm{ppb}$ compared to high resolution samples $(5 \mathrm{~cm})$ at the same depth interval below $450 \mathrm{~m}$ (equivalent to about 6700 years BP). Supposedly, this loss occurred in a dust particle laser counting device, which only the water stream for the low resolution samples had to pass and we corrected the low resolution samples accordingly to averaged high resolution measurements. Low resolution samples above $450 \mathrm{~m}$ depth did not pass the dust device and did not show a systematic offset from the high resolution samples.

Both sites have a low accumulation rate (Fig. 2, below $100 \mathrm{~kg} /$ year $\mathrm{m}^{2}$ ) and are, thus, expected to obtain the majority of the total aerosol flux by dry deposition (Wolff et al., 2006; Fischer et al., 2007a). Therefore, ice concentration records have to be corrected for the diluting/concentrating effect of higher/lower accumulation rate (both temporally as well as spatially upstream for EDML). Accordingly, aerosol fluxes (calculated by multiplying the mean concentration of a certain period with its inferred accumulation rate) are more representative for the atmospheric concentration changes of aerosol at low accumulation sites (Fischer et al., 2007a). The accumulation rates were derived from the stable water isotope temperature records as input to a thermodynamical precipitation model (Fischer et al., 2007a) and are therefore subject to a rather large systematic uncertainty estimated to be around 30\%. The combined error for the nssSO ${ }_{4}^{2-}$ and $\mathrm{NH}_{4}^{+}$deposition fluxes is therefore typically around 35\% as indicated in Fig. 2 by the shaded area. In Fig. 1, the molar ratio between $\mathrm{NH}_{4}^{+}$and nssSO $44-2$ represents an indicator of the degree of neutralization of sulfuric acid by ammonia. Since this parameter is not influenced by the accumulation uncertainty, its error is only $11 \%$.

The depth resolution of the continuous $\mathrm{NH}_{4}^{+}$measurement is typically $1.2 \mathrm{~cm}$ (Kaufmann et al., 2008). For the purpose of this study the records of CFA and IC were down-sampled to a depth scale of $1 \mathrm{~m}$ resolution, the least common denominator. The largest time interval covered by a one meter-average, within the period as far back as 150,000 years BP is 627 years for EDML (on the EDML1 age scale, Ruth et al., 2007), and 206 years for EDC (on the EDC3 time scale, Parrenin et al., 2007). Hence, a common temporal resampling of the records was chosen to be 1000 years to avoid oversampling of the record.

The sea salt (ss) fraction of $\mathrm{Na}^{+}$as well as the non-sea salt (nss) fraction of $\mathrm{Ca}^{2+}$ was calculated according to Bigler et al. (2006) based on the ion composition of $\mathrm{Na}^{+}$and $\mathrm{Ca}^{2+}$ spikes in the EDC record, respectively. Those ratios reflect more closely the partial origin of sea salt aerosol from sea ice formation (Wagenbach et al., 1998; Rankin et al., 2002) and the heterogeneity of the chemical composition of crustal sources. Note that previous $\mathrm{ssNa}^{+}$and $\mathrm{nssCa}^{2+}$ estimates (Wolff et al., 2006) for the EDC ice core used an alternative correction based on average ion compositions of sea water and crustal material. This leads to smaller glacial $s s \mathrm{Na}^{+}$ values in our study compared to the estimate by Wolff et al. (2006) but does not affect the general conclusions drawn in this and earlier papers. A fraction of $\mathrm{SO}_{4}^{2-}$ is contained in sea salt as well. On a seasonal basis, the predominant contribution of $\mathrm{SO}_{4}^{2-}$ aerosols to EDC and EDML is found in summer (Piel et al., 2006; Preunkert et al., 2008) when sea salt aerosol $\left(\mathrm{ssSO}_{4}^{2-}\right.$ ) originates mainly from the open ocean (bulk sea water ion weight ratio of $\left[\mathrm{SO}_{4}^{2-}\right] /$ $\left.\left[\mathrm{Na}^{+}\right]=0.252\right)$. In contrast, the $\mathrm{ssNa}^{+}$aerosol concentrations peak in the austral winter where the sea ice aerosol source is expected to be strongest (ion ratio in sea ice derived sea salt aerosol of 0.07 , Rankin et al., 2002; Weller and Wagenbach, 2007). Here we used the sea ice derived ion ratio to correct for $\mathrm{SsSO}_{4}^{2-}$. Because of the seasonal variation in the origin of sea ice aerosol described above, the corrected $\mathrm{nsSO}_{4}^{2-}$ concentrations will somewhat overestimate the true value. Note, however, that on average sea salt contributes only about $2 \%$ to the total $\mathrm{SO}_{4}^{2-}$ budget at both sites, so this error is negligible.

\section{Results}

The concentration records between the two sites are surprisingly similar for $\mathrm{nsSSO}_{4}^{2-}$ and also for $\mathrm{NH}_{4}^{+}$(Fig. 1). A common intersite variability is confirmed by the correlation coefficient of $r^{2}=0.92(n=150)$ for $\mathrm{nsSSO}_{4}^{2-}$ and $r^{2}=0.75(n=150)$ for $\mathrm{NH}_{4}^{+}$, where the long-term glacial to interglacial changes are responsible for most of the shared variance. However the second order variability on millennial time scale differs between both sites. Furthermore, high concentration values for $\mathrm{NH}_{4}^{+}$in the LGM were approached more gradually at EDC than at EDML, where the values started to increase not before the end of MIS 3. Differences between the two species can be found in Transition 2 (Table 1), in particular the low MIS 5.5 values observed for $\mathrm{NH}_{4}^{+}(\sim 0.44 \mathrm{ppbw})$ compared to the Holocene $(\sim 0.84 \mathrm{ppbw})$ in both cores are not seen in $\mathrm{nsSSO}_{4}^{2-}$. The latter shows comparable concentrations for the last two glacial and interglacial periods, respectively.

As mentioned before, the ancient atmospheric aerosol variability, is better represented by the flux records, which are substantially different from the concentration records and also between the two sites (Fig. 2 and Table 1). The most important feature of both the nssSO ${ }_{4}^{-}$as well as $\mathrm{NH}_{4}^{+}$flux records is the absence of any significant glacial cycles, in contrary to what is found for mineral dust and sea salt aerosol over the last 150,000 years (Fig. 2). The almost constant nssSO ${ }_{4}^{2-}$ flux at EDC has been previously attributed to mostly unchanged marine sulfur productivity in the Indian Ocean sector of the SO and a stable atmospheric transport regime through the late Pleistocene (Wolff et al., 2006). At first glance, the EDML nssSO ${ }_{4}^{2-}$ record confirms this conclusion showing little glacial-interglacial variations, and the inter-site correlation $r^{2}=0.42(n=150)$ is clearly weaker as for the concentration 


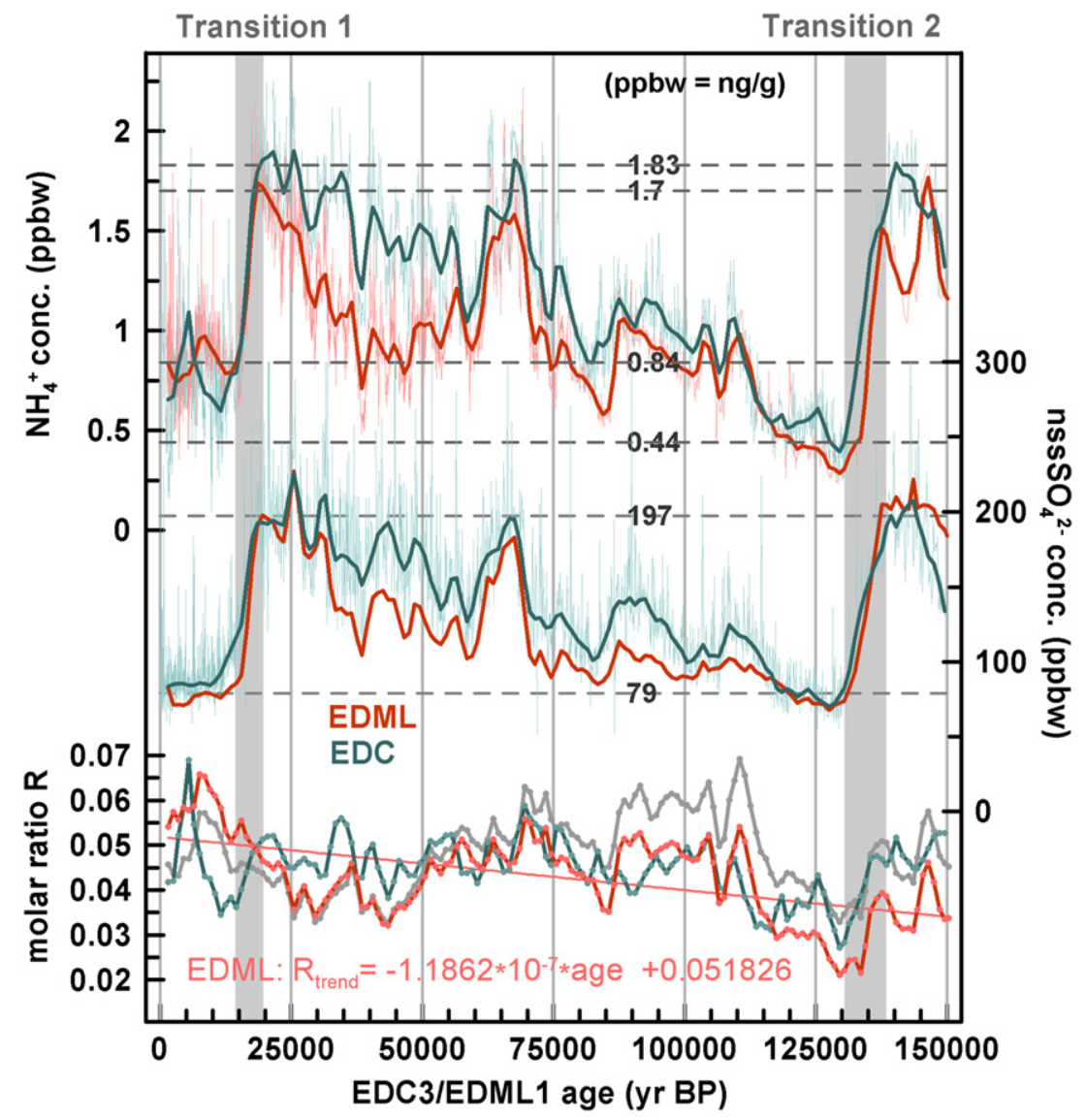

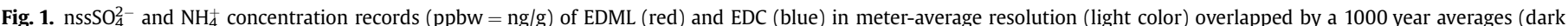
color). The lowermost panel shows the molar $\mathrm{NH}_{4}^{+} / \mathrm{nssSO}_{4}^{2-}$ ratio of the respective cores. Gray line is the EDML molar ratio calculated with detrended $\mathrm{NH}_{4}^{+}$(see text).

records. The changes of the flux at the major transitions as listed in Table 1 hardly ever exceed the uncertainty band of $\pm 35 \%$, which is dominated by the systematic uncertainty of the accumulation rate estimate between glacial and interglacial. Note that this constancy in the flux records implies that the significant variations in concentration records are essentially reflecting the glacial/interglacial changes in snow accumulation rate.

Concerning the significance of any glacial-interglacial change in the fluxes found at EDML compared to EDC, it should be taken into account that a larger fraction of the aerosol is wet deposited at EDML in recent times (Reijmer and Van den Broeke, 2001; Göktas et al., 2002). Therefore, the fluxes of $\mathrm{NH}_{4}^{+}$and nssSO ${ }_{4}^{2-}$ represent conservative indicators for the past atmospheric aerosol concentration change and the true variability would be even lower (corrected for any wet deposition, which is itself dependent on snow

Table 1

Difference (in \%) of the concentration and flux records of nssSO 42 - and $\mathrm{NH}_{4}^{+}$at major transitions.

\begin{tabular}{|c|c|c|c|c|}
\hline & $\mathrm{nsSSO}_{4}^{2-}$ & & $\mathrm{NH}_{4}^{+}$ & \\
\hline & EDC (\%) & EDML (\%) & EDC (\%) & EDML (\%) \\
\hline Flux ${ }^{\mathrm{a}}$ Std-dev. & \pm 20 & \pm 20 & \pm 32 & \pm 21 \\
\hline $\begin{array}{l}\Delta \text { Transition } 1 \text { conc./flux } \\
0-15 \text { kyr BP to } 17.5-25 \text { kyr BP }\end{array}$ & $110 /-1$ & $143 / \mathbf{1 9}$ & $118 / 2$ & $94 /-5$ \\
\hline $\begin{array}{l}\Delta \text { MIS3-4 conc./flux } \\
57-61 \mathrm{kyr} \text { BP to } 65-70 \mathrm{kyr} \text { BP }\end{array}$ & $35 / 6$ & $57 / 18$ & $57 / 23$ & $63 / 23$ \\
\hline $\begin{array}{l}\Delta \text { Transition } 2 \text { conc./flux } \\
127-132 \text { kyr BP to } 137-145 \mathrm{kyr} \text { BP }\end{array}$ & $146 /-8$ & $186 / 4$ & $284 / 44$ & $329 / 55$ \\
\hline
\end{tabular}

${ }^{a}$ Linearly detrended fluxes accumulation). In any case, even the local minima in the EDML fluxes of $\mathrm{nsSOO}_{4}^{2-}$ and $\mathrm{NH}_{4}^{+}$around 12,000 years BP do not clearly exceed the uncertainty band (shaded band in Fig. 2). Furthermore this dip is not visible in the concentration record also pointing at a bias in the accumulation rate estimate.

The overall picture of the $\mathrm{NH}_{4}^{+}$flux records is somewhat more complex; particularly for EDML, where the aerosols were once deposited further upstream (Fischer et al., 2007a), a linear decreasing trend is superimposed on millennial scale variations. For nssSO ${ }_{4}^{2-}$ no such behavior can be detected in the flux record, thus, a spatial $\mathrm{NH}_{4}^{+}$trend would imply an upstream change in the $\mathrm{NH}_{4}^{+} / \mathrm{nsSSO}_{4}^{2-}$ ratio in the aerosol phase on a rather short distance. Unfortunately, so far no firn cores or snow pits along the ice divide upstream of the EDML drill site have been reliably analyzed for $\mathrm{NH}_{4}^{+}$ concentrations to quantify such possible spatial effects. Apart of this linear long-term trend at EDML both flux records in Fig. 2 are nearly constant over the last 150,000 years, similar to what has been observed for nssSO ${ }_{4}^{2-}$. In particular no systematic glacial/ interglacial $\mathrm{NH}_{4}^{+}$changes can be identified albeit a trace of transition 2 is still visible. As for nssSO ${ }_{4}^{2-}$, the inter-site correlation for the flux of $\mathrm{NH}_{4}^{+}$is weak $\left(r^{2}=0.12, n=150\right)$.

\section{Sources of nssSO ${ }_{4}^{2-}$ and $\mathrm{NH}_{4}^{+}$}

In contrast to MSA, which has no significant source besides marine DMS, Antarctic nssSO ${ }_{4}^{2-}$ potentially encounters contributions from the stratosphere, continental aerosol (secondary and terrestrial sulfate) and from volcanism. The volcanic nssSO ${ }_{4}^{--}$flux occurs mainly sporadically after individual eruptions. The average 


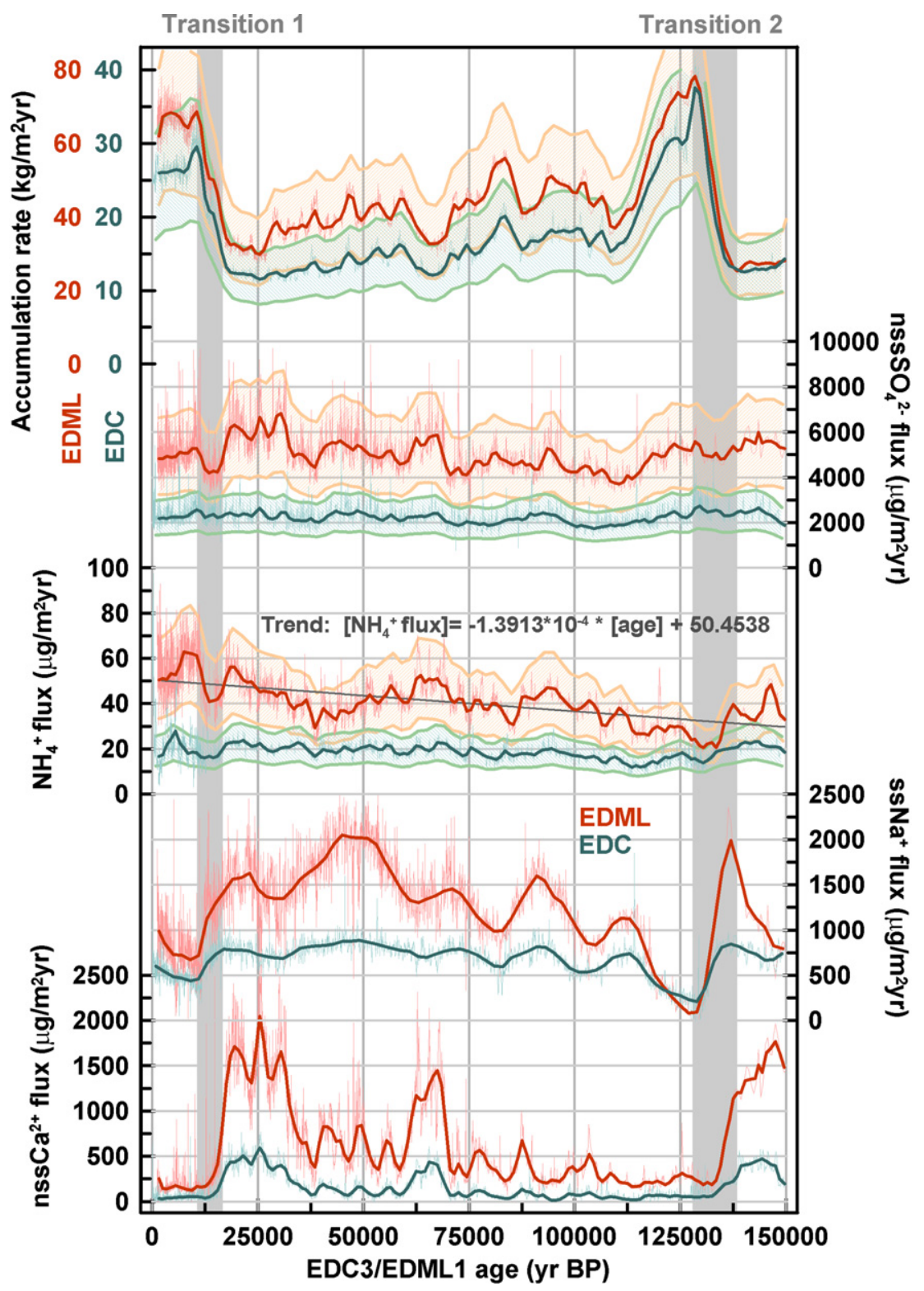

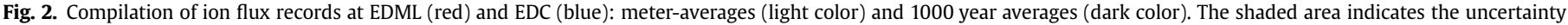
band of the flux $(1 \sigma=35 \%)$ and accumulation $(30 \%)$.

flux per volcano for the last 2000 years at EDML was about $15,000 \mu \mathrm{g} / \mathrm{m}^{2}$ and the typical frequency of a volcanic horizon in the ice was about 0.0271 /year (Traufetter et al., 2004). In contrast, the total $\mathrm{nsSO}_{4}^{2-}$ flux in Fig. 2 is about $5000 \mu \mathrm{g} / \mathrm{m}^{2}$ year for EDML and $2000 \mu \mathrm{g} / \mathrm{m}^{2}$ year for EDC, respectively. Accordingly, we derive an average volcanic contribution to the total nssSO ${ }_{4}^{2-}$ flux (1000 year averages) in Fig. 2 of only about 8\% for EDML. This is comparable to the volcanic sulfate contribution at EDC of 6\% (Castellano et al., 2005). More importantly, there is little change in the frequency of volcanic eruptions in the southern hemisphere between glacial and interglacial (Castellano et al., 2003), implying no systematic difference in the volcanic contribution to the total nssSO ${ }_{4}^{2-}$ flux. Accordingly, we made no correction of the $\mathrm{nsSSO}_{4}^{2-}$ values for volcanogenic sulfate deposition.

The estimate of the other contributions to $\mathrm{nsSSO}_{4}^{2-}$ is more difficult as few studies are available to our knowledge. Minikin et al. (1998) investigated the non-DMS nssSO ${ }_{4}^{-}$fraction in Antarctic aerosol samples, which is found to account for less than $10 \%$ of the mean atmospheric nssSO ${ }_{4}^{2-}$ level. Their tracer supported estimates revealed that the majority of this fraction $(85 \%)$ is nowadays made up by continental submicron sulfate whereas the stratospheric and terrigeneous sulfate contributions are playing a minor role. During glacial time, however, when the mineral dust flux (atmospheric load) over the interior Antarctica is enhanced by a factor of $\sim 25$ (Lambert et al., 2008) the latter sulfate source might have been more important. By use of the mean EDML nssSO $4^{2-}$ flux $(5000 \mu \mathrm{g} /$ $\mathrm{m}^{2}$ year) and a maximum glacial $\mathrm{nssCa}^{2+}$ flux $\left(1600 \mu \mathrm{g} / \mathrm{m}^{2}\right.$ year $)$ and furthermore assuming a mean sediment $\mathrm{SO}_{4}^{2-}$ to $\mathrm{Ca}^{2+}$ ratio of 0.1 (Bowen, 1979) the terrigeneous sulfate contribution can be neglected. However, to define an upper most limit, we use a $\mathrm{SO}_{4}^{2-}$ to $\mathrm{Ca}^{2+}$ ratio of 0.5 (observed in preindustrial Saharan dust plumes by Wagenbach et al., 1996) and we obtain a maximum terrigeneous fraction of $16 \%$. Referring to a typical interglacial $\mathrm{nsca}^{2+}$ flux level of only around $250 \mathrm{~g} / \mathrm{m}^{2}$ year this figure is reduced to $2.5 \%$. Note, that the deployed $\mathrm{SO}_{4}^{2-}$ to $\mathrm{Ca}^{2+}$ ratio in Saharan dust can most likely not be directly applied to dust in Antarctica from Patagonian origin 
and may be overestimated, due to contributions from non-terrigeneous $\mathrm{SO}_{4}^{2-}$. Investigations on sulfate isotopes from ice cores by Alexander et al. (2003) revealed that neither the dust (7\%) nor the stratospheric contribution play a major role, in line with our findings.

Vice versa, taking the absence of glacial-interglacial cycles for the $\mathrm{nsSO}_{4}^{2-}$ flux into account (Fig. 2), we argue that the mineral dust contribution is minor and may only be apparent in the second order variability of $\mathrm{nsSOO}_{4}^{2-}$. Our long-term $\mathrm{nssSO}_{4}^{2-}$ record is clearly dominated by marine biogenic sulfur throughout the last 150,000 years.

In contrast to Greenland, where most of the $\mathrm{NH}_{4}^{+}$originates from soil emission and biomass burning (Fuhrer and Legrand, 1997), the major ammonium aerosol source for the interior Antarctica has been supposed to be located in the SO (Legrand et al., 1998, 1999; Sommer et al., 2000). Orthogenic $\mathrm{NH}_{4}^{+}$emission related to local Penguin colonies may be important for the local budget at coastal Antarctic stations but account only for a minor part of the $\mathrm{NH}_{4}^{+}$budget in the interior of Antarctica (Legrand et al., 1998; Rankin and Wolff, 2000). Furthermore, no potential anthropogenic increase since preindustrial times (Galloway et al., 2004; Tsigaridis et al., 2006) is visible in Antarctic firn $\mathrm{NH}_{4}^{+}$flux records (Sommer et al., 2000). The life time estimate for particulate $\mathrm{NH}_{4}^{+}$is of a few days (Adams et al., 1999). Accordingly, a low continental $\mathrm{NH}_{4}^{+}$input into Antarctica is in line with the rapid removal from the atmosphere during transport. Thus, the Southern Ocean is most likely the major source of $\mathrm{NH}_{4}^{+}$for the interior of Antarctica.

To pin down the seasonal timing of the transport of $\mathrm{NH}_{4}^{+}$aerosols from the ocean to the remote ice sheet, we focus on atmospheric and firn core measurements. Only a few reliable aerosol $\mathrm{NH}_{4}^{+}$data are available from Antarctica, as these samples are easily contaminated during sampling and storage (Silvente and Legrand, 1993; Legrand et al., 1998; Littot et al., 2002). To investigate the arrival of the major $\mathrm{NH}_{4}^{+}$aerosol load at EDML in recent time, firn core analysis in sub seasonal resolution can provide assistance. CFA measurements of the B33 firn core from a site close to EDML extending over the past 2000 years feature a $\sim 2$ month delay of the $\mathrm{NH}_{4}^{+}$aerosol peak compared to $\mathrm{Na}^{+}$, which peaks in September (Sommer et al., 2000; Weller and Wagenbach, 2007). Therefore $\mathrm{NH}_{4}^{+}$aerosol concentrations peak in spring/summer slightly earlier in the year than $\mathrm{nsSO}_{4}^{2-}$ which has its maximum in December/ January at EDML and EDC, simultaneously to the corresponding aerosol load at the coastal stations of Neumayer and Dumont d'Urville (Minikin et al., 1998; Piel et al., 2006; Preunkert et al., 2008). The nssSO ${ }_{4}^{2-}$ peak is in phase with the source strength of the marine $\mathrm{nsSO}_{4}^{2-}$ source between 58 and $66^{\circ} \mathrm{S}$ (Minikin et al., 1998; Cosme et al., 2005; Preunkert et al., 2007). This seasonal decoupling shows that although the transport of $\mathrm{NH}_{4}^{+}$to the ice sheet requires acidic aerosol it is not entirely controlled by the sulfate aerosol concentration.

The preceding $\mathrm{NH}_{4}^{+}$peak could be an indication that the dominant $\mathrm{NH}_{4}^{+}$source region lies in a more northerly band of the SO compared to the DMSP emission maximum and is less influenced by the seasonal sea ice coverage. Legrand et al. (1998) found a roughly simultaneous peak for both species measured in coastal aerosol. This is not necessarily contradictory to the preceding $\mathrm{NH}_{4}^{+}$ peak at EDML as the SO source areas seen at the coastal sites are located close to the sampling site.

This argumentation provides further evidence that the $\mathrm{NH}_{4}^{+}$ investigated in ice cores far inland Antarctica originate mainly from the MBL above the SO, from a source region which is at least partly congruent to the one of marine $\mathrm{nsSO}_{4}^{2-}$ and most likely also partly due to additional marine $\mathrm{NH}_{4}^{+}$sources located north of the primary nssSO ${ }_{4}^{2-}$ production region. Thus, this record can potentially serve as a complementary proxy for the marine biogenic activity.

\section{The molar $\mathrm{NH}_{4}^{+} / \mathrm{nssSO}_{4}^{2-}$ ratio}

The average molar ratios of $\left[\mathrm{NH}_{4}^{+}\right] /\left[\mathrm{nssSO}_{4}^{2-}\right]\left(R_{\mathrm{NS}}\right)$ on the Antarctic plateau are very low (around 0.05 , Fig. 1 ) and at surprisingly similar level for both sites. Also the studies of Legrand et al. $(1998,1999)$ provided $R_{\mathrm{NS}}$ with typical values for inner Antarctica in the range of 0.1 and for costal snow of about 0.3 . Several studies on marine aerosol agree on a ratio on the order of 0.3 for aerosols transported in an air parcel originating from the remote Southern ocean (O'Dowd et al., 1997; Norman et al., 2003; Norman and Leck, 2005; Virkkula et al., 2006; Ooki et al., 2007). Note that measured $R_{\mathrm{NS}}$ in the SO region is always far from complete neutralization of sulfate aerosol; accordingly, the availability of acidic sulfate aerosol does not stoichiometrically limit the atmospheric $\mathrm{NH}_{4}^{+}$concentration. The measured $R_{\mathrm{NS}}$ values fit with results of the co-emission model by Johnson and Bell (2008) that leads to a $R_{\mathrm{NS}}$ in the range of 0.3 (at $T=0{ }^{\circ} \mathrm{C}$ and sulfate-input $=0.5 \mathrm{nmol} / \mathrm{m}^{2} \mathrm{~min}$ ) but is dependent on the choice of the sea surface temperature. Further north the ratio increases (O'Dowd et al., 1997), where the nssSO ${ }_{4}^{2-}$ becomes rather neutralized by $\mathrm{NH}_{4}^{+}$, i.e. $R_{\mathrm{NS}}$ is between 1 and 2 . This may be related to a continuing marine emission of $\mathrm{NH}_{4}^{+}$in regions of declining DMS production or to an increasing contribution of continental $\mathrm{NH}_{4}^{+}$sources in lower latitudes.

Referring to the typically $R_{\mathrm{NS}}$ value of 0.3 within the MBL source region relevant for the interior of Antarctica, an almost one order of magnitude depletion of this ratio is needed to achieve the values observed at EDML and EDC. The $R_{\mathrm{NS}}$ of ammonium sulfate aerosol in an isolated, marine air mass traveling over the ice sheet is expected to steadily decrease as nssSO ${ }_{4}^{2-}$ builds up from the $\mathrm{SO}_{2}$ (DMS) precursor, whereas the extremely low atmospheric $\mathrm{NH}_{3}$ level (with respect to $\mathrm{NH}_{4}^{+}$) may be neglected for subsequent $\mathrm{NH}_{4}^{+}$formation. $\mathrm{A}$ similar situation holds for the MSA/nssSO22 system (though more complicated), where a systematic decrease in the $\mathrm{MSA} / \mathrm{nssSO}_{4}^{2-}$ ratio was observed in aerosol samples going from costal regions towards interior Antarctica (Table 2). Minikin et al. (1994), Piel et al. (2006) and Preunkert et al. (2008) suggest that the oxidation of (marine) $\mathrm{SO}_{2}$ during transport onto the plateau could significantly increase the $\mathrm{SO}_{4}^{2-}$ concentration therefore lowering the MSA/ $\mathrm{nssSO}_{4}^{2-}$ ratio. However, respective depletions observed so far hardly exceed a factor of two and are much smaller than our change in the $\mathrm{NH}_{4}^{+} / \mathrm{nssSO}_{4}^{2-}$ ratio. However, we may expect $R_{\mathrm{NS}}$ values much lower than 0.3 above the MBL of the SO, hence in air masses readily to be transported onto the high plateau. This is due to the very rapid nucleation of $\mathrm{NH}_{3}$ in the highly acidic MBL of the SO, leading to a stronger vertical $\mathrm{NH}_{3}$ depletion, whereas the $\mathrm{SO}_{2}$ lifetime is sufficiently large to reach the free troposphere, where additional sulfate but almost no additional $\mathrm{NH}_{4}^{+}$is produced (Davis et al., 1998; Adams et al., 1999; Preunkert et al., 2008). Accordingly, we suggest that the $\mathrm{NH}_{4}^{+}$bearing aerosol providing $\mathrm{NH}_{4}^{+}$to the interior of the Antarctic ice sheets may have initially derived from the free troposphere over the SO, starting already with a lowered $R_{\mathrm{NS}}$, which is further enriched in $\mathrm{SO}_{4}^{2-}$ during transport.

Table 2

Typical values for the molar ratio of $\mathrm{NH}_{4}^{+} / \mathrm{nssSO}_{4}^{2-}\left(R_{\mathrm{NS}}\right)$ and $\mathrm{MSA} / \mathrm{nssSO}_{4}^{2-}$ are shown. $R_{\mathrm{NS}}$ values were summarized from references in this publication (e.g. Silvente and Legrand, 1993; Norman et al., 2003; Virkkula et al., 2006) and from our own records.

\begin{tabular}{lll}
\hline & $\begin{array}{l}\text { Typical molar ratios } \\
\text { for } \mathrm{NH}_{4}^{+} / \mathrm{nsSSO}_{4}^{2-}\end{array}$ & MSA/nssSO ${ }^{2-\mathrm{a}}$ \\
\hline Remote SO from $\sim 60^{\circ} \mathrm{S}, \mathrm{ACZ}$ & $0.3-0.42$ & $0.2-0.3$ \\
Coastal Antarctica & 0.3 & $0.1-0.2$ \\
Interior Antarctica & $0.05-0.1$ & . \\
\hline
\end{tabular}

a Molar ratios of $[\mathrm{MSA}] /\left[\mathrm{nsSSO}_{4}^{2-}\right]$ from Legrand and Pasteur (1998), Piel et al. (2006), and Preunkert et al. (2008) and references therein. 


\section{Biogenic productivity tracers from the Southern Ocean}

The most conspicuous feature of the $\mathrm{NH}_{4}^{+}$and $\mathrm{nsSOO}_{4}^{2-}$ flux records in Fig. 2 is the absence of any significant glacial/interglacial variations. It seems unlikely that different climate parameters have been balanced exactly to keep the fluxes on a constant level (Wolff et al., 2006), although such a compensation cannot be entirely ruled out on the basis of currently available data. Since $R_{\mathrm{NS}}$ values at the source are at the same time always far from neutralization and the $\mathrm{NH}_{4}^{+}$aerosol content being, therefore, not limited by atmospheric sulfate concentrations, we conclude that both the biogenic sulfur as well as the biogenic production of reduced nitrogen in the SO remained rather stable between glacials and interglacials. From this it follows that also the production of both marine biogenic sulfur and nitrogen had most likely not changed substantially between glacial and interglacial.

When looking in more detail, secondary changes in the $\mathrm{NH}_{4}^{+}$and nssSO ${ }_{4}^{2-}$ flux records on the order of $<30 \%$ can be observed. These could be entirely explained by a systematic error in the accumulation rate estimate. Nevertheless, in the following the potential contributions of individual processes such as iron fertilization, sea ice extent and transport to these subdued millennial variations will be discussed.

\subsection{The effect of iron fertilization}

The mobilization of aeolian dust in Patagonia was drastically stronger during glacial periods than it is today (Basile et al., 1997; Lambert et al., 2008). As a consequence, dust fluxes towards Antarctica were on average 25 times higher in the glacial compared to warm stages (Lambert et al., 2008), with three times higher dust flux at EDML than at EDC (Fig. 2 and Fischer et al., 2007a). Apart from, the difference in the accumulation rate this is mainly due to the distance of both drill sites to the dominant Patagonian source, and, in principle, should result in a higher input of dust to the Atlantic sector compared to the Indian sector of the SO, affecting the growth of phytoplankton. The macronutrient supply in the SO is in principle sufficient to enable a high biological productivity, however, at the present state only relatively small amounts of chlorophyll, as indicator for algae growth, are observed (Martin et al., 1990). This is attributed to an insufficient supply of iron, strongly limiting the growth of phytoplankton. While an influence of iron input on export production, determining the storage of biogenic carbon in the abyss, could not be ascertained, an unequivocal fertilization effect on primary production has been proven by nutrient fertilization studies in the SO (Coale et al., 1996; Smetacek, 1998; Ridgwell and Watson, 2002; Buesseler and Boyd, 2003). In glacial periods, when the input of aeolian dust and, thus, iron to the SO was strongly increased (Gaspari et al., 2006), the iron limitation may have possibly been abolished, enabling enhanced biological productivity (Martin et al., 1990; Martínez-Garcia et al., 2009). Note, that recent studies on opal production in the SO show the highest opal sediment fluxes during the glacial/interglacial transition and during the warm events in MIS 3, where dust levels were decreased from the LGM maximum and atmospheric $\mathrm{CO}_{2}$ was nevertheless higher (Anderson et al., 2009).

Alternatively, a higher utilization of macronutrients at the surface during the glacial could be also explained by a higher surface stratification (Francois et al., 1997), leading to a more complete use of the reduced upwelling flux of macronutrients from below. A change in the mixed layer depth generally leads also to a change in the DMS production (Simo and Pedros-Alio, 1999), hence $\mathrm{nsSO}_{4}^{2-}$ in the atmosphere. Again, the absence of any significant trend in the nssSO ${ }_{4}^{2-}$ flux in our records questions changes in the mixed layer depth. However, the parameterization by Simo and Pedros-Alio (1999) may not be directly applicable to the $S O$ seasonal sea ice zone.

A similar temporal evolution of dust deposition (represented by the dust component $\mathrm{nsSCa}^{2+}$ ) and of the small changes in glacial nssSO ${ }_{4}^{2-}$ fluxes in the EDML core might indicate iron fertilization in the Atlantic sector of the SO. A correlation of $r^{2}=0.50(n=943)$ between the fluxes of $\mathrm{nsSCa}^{2+}$ and $\mathrm{nsSSO}_{4}^{2-}$ can be found during MIS 2-4 (Fig. 3), however, when taking the whole data set into account (including interglacials and glacial maxima) the correlation coefficient drops to $0.30(n=2284)$. When looking more closely at Fig. 3, a significant nssSO ${ }_{4}^{2-}$ increase can only be identified at EDML when $\mathrm{nssCa}^{2+}$ fluxes exceed approximately $600 \mu \mathrm{g} / \mathrm{m}^{2}$ year. From this point on, the nssSO ${ }_{4}^{2-}$ flux increases from a rather constant level of $500 \mu \mathrm{g} / \mathrm{m}^{2}$ year by up to $30 \%$. At EDC this $\mathrm{nssCa}^{2+}$ threshold is never passed and nssSO ${ }_{4}^{2-}$ fluxes appear to remain constant throughout the records.

For $\mathrm{NH}_{4}^{+}$the correlation with $\mathrm{nssCa}^{2+}$ is weaker $\left(r^{2}=0.28\right.$, $n=938$ ) but still significantly different from zero on the $99 \%$ significance level. However, if we correct for a potential upstream trend in the EDML $\mathrm{NH}_{4}^{+}$flux and accordingly compensate for this linear decrease, the weak correlation to $\mathrm{nssCa}^{2+}$ disappears $\left(r^{2}=0.09, n=938\right)$. Thus, no significant increase in the $\mathrm{NH}_{4}^{+}$flux can be observed in parallel to nssCa ${ }^{2+}$ changes at either EPICA drill site. Accordingly, in the Atlantic sector, the nssSO ${ }_{4}^{2-}$ record may suggest a weak coupling of biogenic nssSO ${ }_{4}^{2-}$ production with the dust input, when a certain dust threshold is exceeded, however, this is not corroborated by the $\mathrm{NH}_{4}^{+}$record. Note, that this nssSO ${ }_{4}^{2-}$ increase is still within the uncertainty introduced by the accumulation rate estimate used to calculate fluxes and, therefore, may be erroneous. Moreover, when allowing for a potential contribution of terrigeneous $\mathrm{nsSSO}_{4}^{2-}$ caused by increased mineral dust deposition in Antarctica this increase is even smaller or completely absent. Hence the dust flux to the SO seems not to have significantly affected the productivity of the marine biota over the last 150,000 years.

\subsection{The effect of sea ice}

Marine biological productivity is potentially affected by sea ice conditions in various ways. For example a region covered completely and continuously by sea ice is not available for the growth of phytoplankton. Furthermore, the timing of the melting and growth of seasonal sea ice affects algal blooms. Also a repository function of sea ice for dust deposited during winter has been suggested (Sedwick and DiTullio, 1997).

Modern as well as LGM sea ice conditions have been reconstructed by Gersonde et al. (2005). In the LGM, a maximum summer sea ice extent (SIE) at approximately the modern winter SIE is suggested for the Atlantic sector, whereas the maximum winter SIE was shifted by about $10^{\circ}$ to the north up to $47^{\circ} \mathrm{S}$. In the southern Indian Ocean, the differences between summer and winter SIE during the LGM were more pronounced than the modern SIE variability. The glacial summer-SIE is near the modern summer sea ice edge and a largely extended winter sea ice edge proceeded up to about $57^{\circ} \mathrm{S}$. Hence, seasonal sea ice in the Indian Ocean sector has decreased strongly from the LGM to the Holocene whereas the sea ice seasonality in the Atlantic sector underwent a slight decrease only.

Several studies support the assignment of $\mathrm{ssNa}^{+}$records from Antarctic ice cores mainly to the production of sea ice in the SO. Sea ice derived $\mathrm{ssNa}^{+}$is supposed to stem mainly from frost flower production at the surface (Rankin et al., 2002) or the blowing of salt depleted sea spray onto fresh snow lying on the sea ice (Yang et al., 2008), and should be closely coupled to the formation of sea ice and a first order estimate of the total sea ice area (Iizuka et al., 2008). Comparing the fluxes of $\mathrm{nsSOO}_{4}^{2-}$ and $\mathrm{NH}_{4}^{+}$with $\mathrm{ssNa}^{+}$does not 

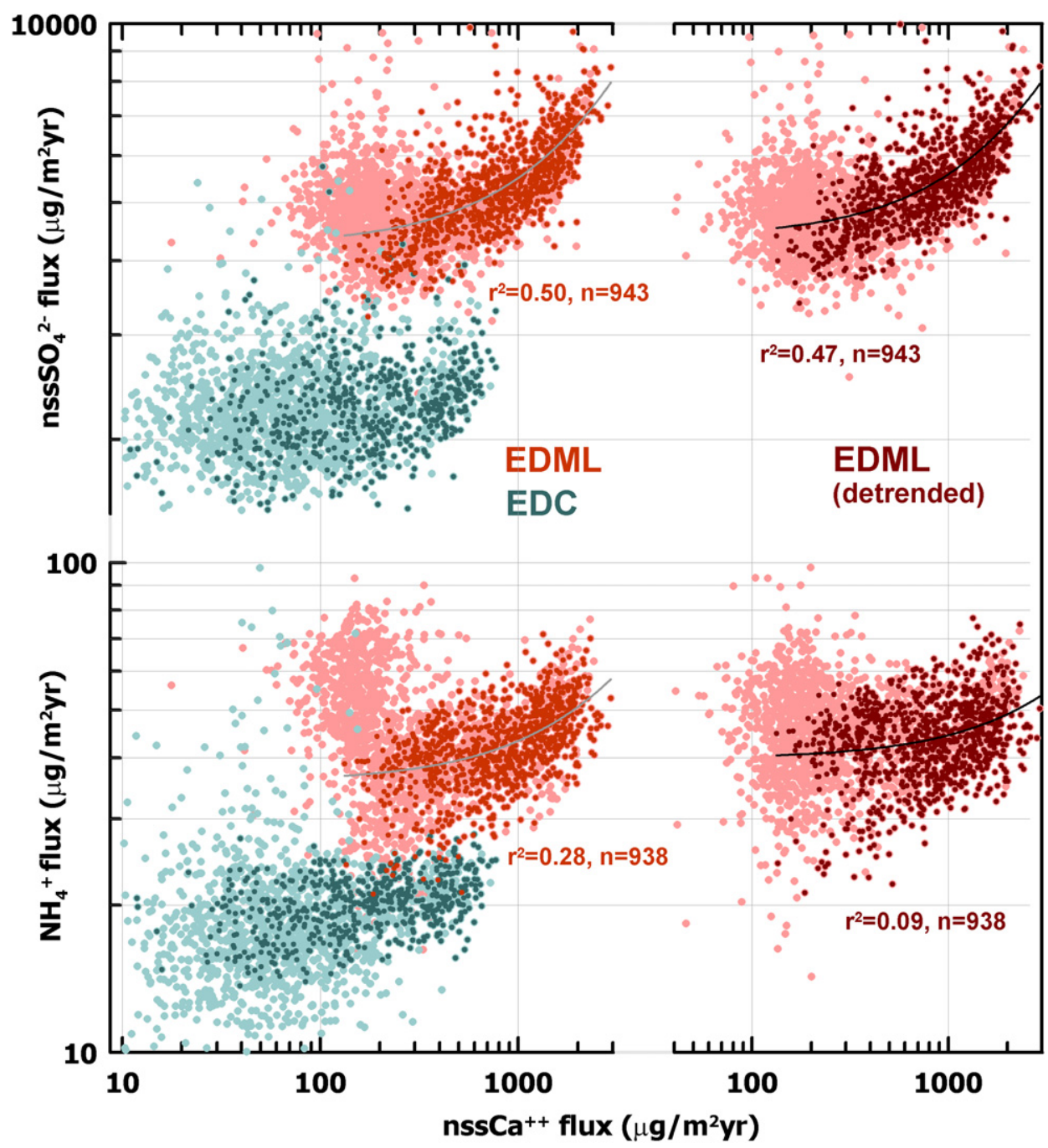

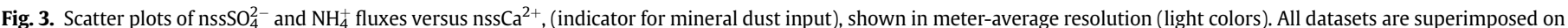

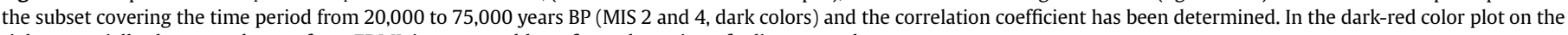
right essentially the same dataset from EDML is presented but after subtraction of a linear trend.

support a coupling of a production of $\mathrm{nsSO}_{4}^{2-}$ and sea ice on long time scale, as illustrated by the lack of correlation between records in Fig. 4.

For EDC, the constancy of our records can be attributed to a summer-SIE which potentially retreated to rather the same latitude over time. But at EDML, the temporally constant seasonal sea ice area in the Atlantic sector of the SO combined with the shift of the seasonal sea ice edge should cause a decrease in air concentration of sulfate as the distance to the source is longer. However, over time $\mathrm{nsSO}_{4}^{2-}$ remains on the same level and consequently, the position of the summer sea ice edge seems to have no dominant effect on the nssSO ${ }_{4}^{2-}$ flux records at both sites. Also Preunkert et al. (2007) have not found a clear dependency between MSA aerosol measured at Dumont d'Urville and the sea ice extent for recent time. This is in contradiction to results from Law Dome, Antarctica, where a correlation between recent maximum SIE in the adjacent ocean and MSA in the ice is observed (Curran et al., 2003). However, the coupling between DMS production and SIE may spatially vary (Abram et al., 2007). In any case, the recovered ice core records of nssSO ${ }_{4}^{-}$and $\mathrm{NH}_{4}^{+}$seem not to be affected by the sea ice coverage on the long time scale.

\subsection{The effect of transport}

In addition to potential changes in the source strength of $\mathrm{NH}_{4}^{+}$ and $\mathrm{nsSO}_{4}^{2-}$ aerosol due to a change in biological activity, also changes in the transport efficiency could lead to changes in the atmospheric aerosol concentration in the interior of the Antarctic ice sheet. In this respect an often encountered conjecture on the atmospheric circulation in the SO during glacials is an increase in westerly winds and cyclonic activity due to the increased pole to equator temperature gradient. Coupled general circulation models, however, do not unambiguously support this conjecture (Menviel et al., 2008). In addition, model studies looking at transport of mineral dust from Patagonia suggest only a small decrease or even an increase in transport time to Antarctica (Reader et al., 1999; Lunt and Valdes, 2001). The same holds true for dust transport time estimates based on the differential dust change between the EDML and EDC ice core (Fischer et al., 2007b). However, those models and observations on mineral dust need not necessarily hold for the transport of marine biogenic species, which are transported from the open ocean surface to Antarctica in lower altitudes and which exhibit a strongly different life time. In the publication of 


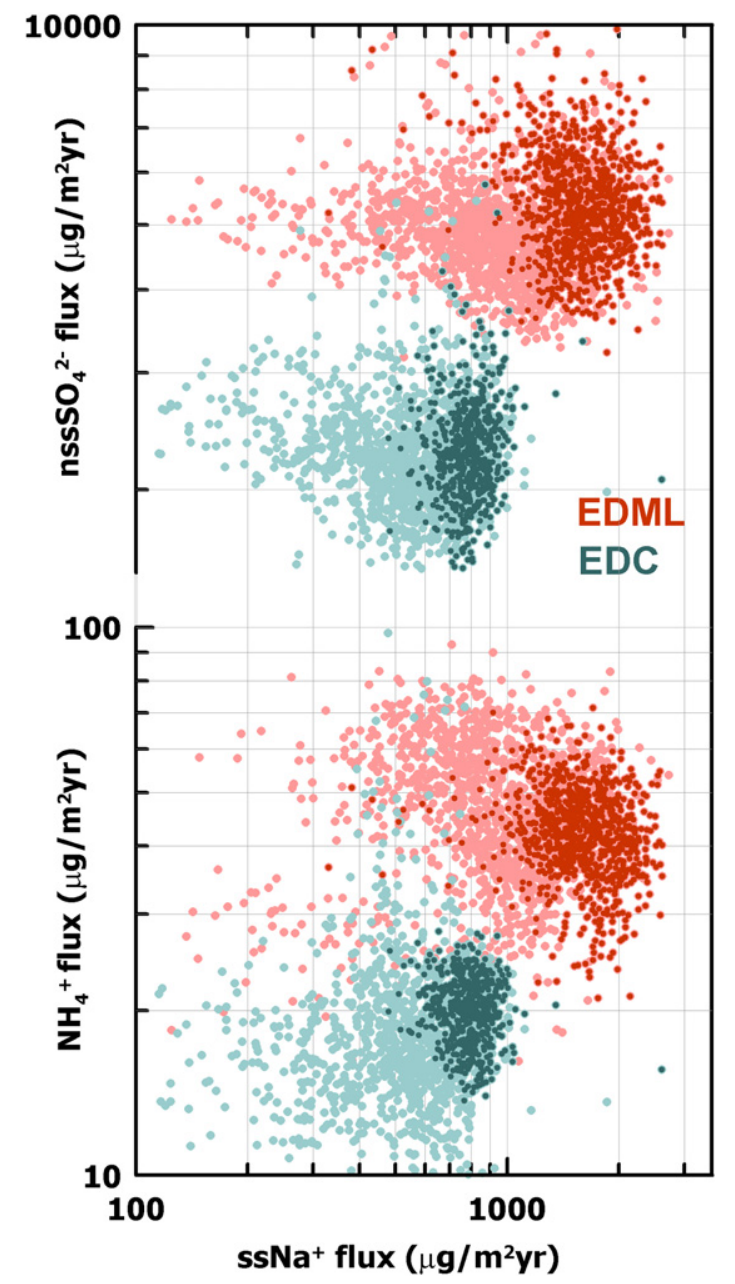

Fig. 4. In this correlation scatter plots the fluxes of $\mathrm{nssSO}_{4}^{2-}$ and $\mathrm{NH}_{4}^{+}$versus $\mathrm{ssNa}^{+}$, a first order indicator for the sea ice area, are shown in meter-average resolution (light colors) superimposed by the subset covering the time period from 20 to $75 \mathrm{ka} \mathrm{BP}$ (MIS 2 and 4 , dark colors).

Castebrunet et al. (2006) a sulfur chemistry model was combined with an atmospheric general circulation model to study the production of biogenic sulfur aerosol and its transport from the SO towards interior Antarctica for Holocene as well as LGM conditions. They found that the biology of DMS production shows little variation over this time period and could approve the constant fluxes of nssSO ${ }_{4}^{2-}$ in the EDC ice core.

As a first order estimate whether a change in transport efficiency is able to explain the variability observed in the fluxes of nssSO ${ }_{4}^{2-}$ and $\mathrm{NH}_{4}^{+}$at EDML and EDC, we use a one-dimensional transport model according to Fischer et al. (2007a) with $c_{\text {air }}(t)=c_{\text {air }}(t=0) \exp (-t / \tau)$. The transport time has been set to $t=5$ days (Reijmer et al., 2002) and the residence time to $\tau=4$ days, but other reasonable parameter-sets would not affect the outcome significantly. In the absence of air concentration values of $\mathrm{nsSO}_{4}^{2-}$ and $\mathrm{NH}_{4}^{+}$, we use the flux as determined from the ice core as representative for $c_{\text {air }}(t)$. Consequently, the assumption of transport being solely responsible (no change in source strength, $\left.c_{\text {air }}(t=0)_{\text {Holocene }}=c_{\text {air }}(t=0)_{\mathrm{LGM}}\right)$ for the observed $20 \%$ short-term variability would imply travel time changes on the order of $16 \%$. This is similar to the range suggested by model studies of transport time during the LGM towards southern Polar Regions (Krinner and Genthon, 2003). Consequently, we cannot exclude transport changes as a cause for the secondary variability of the nssSO ${ }_{4}^{2-}$ and $\mathrm{NH}_{4}^{+}$fluxes at EDML and EDC. Again, we have to stress that those small variations may be entirely explained by systematic errors in the accumulation rate estimate used to calculate aerosol fluxes.

\section{Conclusions}

The constancy of the fluxes of $\mathrm{NH}_{4}^{+}$and $\mathrm{nsSOO}_{4}^{2-}$ found in the EPICA ice cores in the Indian but also in the Atlantic Sector of interior Antarctica, is an indicator for the absence of significant changes in the marine biological activity over the last 150,000 years. For the first time, a reliable and long-term $\mathrm{NH}_{4}^{+}$flux record is presented that may serve as additional quantitative biological productivity proxy, which in contrast to nssSO ${ }_{4}^{2-}$ would be more representative for the entire biomass production processes in the Southern Ocean (SO). Both species, however, interact at the marine source (co-emission concept), leading to a partial neutralization of acidic $\mathrm{nsSO}_{4}^{2-}$ by $\mathrm{NH}_{4}^{+}$. The lack of correlation between our records and $\mathrm{ssNa}^{+}$(a marker for the sea ice extent) in contrast to the short atmospheric residence time brings further evidence that the seasonal biological activity took place north of the summer sea ice edge. Surprisingly, the enhanced mineral dust deposition to the SO in glacial time seems not to have substantially affected neither the $\mathrm{nsSO}_{4}^{2-}$ nor the $\mathrm{NH}_{4}^{+}$aerosol load in interior Antarctica, and, hence, the productivity in the SO. This is in contradiction with the iron fertilization hypothesis and argues against strong changes in biological productivity in the SO, both in the Atlantic as well as in the Indian Ocean.

The secondary variation $(<30 \%)$ of the $\mathrm{NH}_{4}^{+}$and $\mathrm{nsSO}_{4}^{2-}$ flux records lie within the range of the variability of transport and potential changes in source strength but may also be related to a systematic error in the accumulation rate estimate used to calculate deposition fluxes. Furthermore, an obvious trend in the EDML $\mathrm{NH}_{4}^{+}$data (Fig. 2), possibly attributed to an upstream effect, is an open issue that needs further investigations. For this, shallow ice core and snow pit samples investigated with a field-deployable CFA system could provide reliable data. To confirm our conclusion, yeararound $\mathrm{NH}_{4}^{+}$aerosol monitoring at Dome $\mathrm{C}$ and EDML would be helpful as providing essential information about the transport to interior Antarctica and the exact timing of the seasonal maximum relative to $\mathrm{nsSSO}_{4}^{2-}$.

\section{Acknowledgements}

Financial support by the Swiss National Science Foundation is acknowledged. We thank Susanne Preunkert, Martin Johnson and Thomas Stocker for fruitful comments and support. This document was produced with the financial help of the Prince Albert II of Monaco Foundation.

This work is a contribution to the European Project for Ice Coring in Antarctica (EPICA), a joint European Science Foundation/European Commission scientific program, funded by the EU and by national contributions from Belgium, Denmark, France, Germany, Italy, the Netherlands, Norway, Sweden, Switzerland and the United Kingdom. The main logistic support was provided by IPEV and PNRA (at Dome C) and AWI (at Dronning Maud Land). This is EPICA publication no. 230.

\section{References}

Abram, N.J., Mulvaney, R., Wolff, E.W., Mudelsee, M., 2007. Ice core records as sea ice proxies: an evaluation from the Weddell Sea region of Antarctica. Journal of Geophysical Research 112, D15101. doi:10.1029/2006JD008139.

Adams, P.J., Seinfeld, J.H., Koch, D.M., 1999. Global concentrations of tropospheric sulfate, nitrate, and ammonium aerosol simulated in a general circulation model. Journal of Geophysical Research 104, 13791-13823. 
Alexander, B., Thiemens, M.H., Farquhar, J., Kaufman, A.J., Savarino, J., Delmas, R.J., 2003. East Antarctic ice core sulfur isotope measurements over a complete glacial-interglacial cycle. Journal of Geophysical Research 108, 4786. doi:10.1029/2003JD003513.

Anderson, R.F., Ali, S., Bradtmiller, L.I., Nielsen, S.H.H., Fleisher, M.Q., Anderson, B.E., Burckle, L.H., 2009. Wind-driven upwelling in the Southern Ocean and the deglacial rise in atmospheric $\mathrm{CO}_{2}$. Science 323, 1443-1448.

Andreae, M.O., Andreae, T.W., Meyerdierks, D., Thiel, C., 2003. Marine sulfur cycling and the atmospheric aerosol over the springtime North Atlantic. Chemosphere 52, 1321-1343.

Basile, I., Grousset, F.E., Revel, M., Petit, J.R., Biscaye, P.E., Barkov, N.I., 1997. Patagonian origin of glacial dust deposited in East Antarctica (Vostok and Dome C) during glacial stages 2, 4 and 6. Earth and Planetary Science Letters 146, 573-589.

Berresheim, H., 1987. Biogenic sulfur emissions from the sub-Antarctic and Antarctic oceans. Journal of Geophysical Research 92, 13245-13262.

Bigler, M., Röthlisberger, R., Lambert, F., Stocker, T.F., Wagenbach, D., 2006. Aerosol deposited in East Antarctica, over the last glacial cycle: detailed apportionment of continental and sea salt contributions. Journal of Geophysical ResearchAtmospheres 111, D03102. doi:10.1029/005JD006349.

Bopp, L., Kohfeld, K.E., Le Quere, C., Aumont, O., 2003. Dust impact on marine biota and atmospheric CO2 during glacial periods. Paleoceanography 18, 1046.

Bouwman, A.F., Lee, D.S., Asman, W.A.H., Dentener, F.J., VanderHoek, K.W., Olivier, J.G.J., 1997. A global high-resolution emission inventory for ammonia. Global Biogeochemical Cycles 11, 561-587.

Bowen, H.J.M., 1979. Environmental Chemistry of the Elements. Elsevier, New York.

Boyd, P.W., Watson, A.J., Law, C.S., Abraham, E.R., Trull, T., Murdoch, R, Bakker, D.C.E., Bowie, A.R., Buesseler, K.O., Chang, H., Charette, M., Croot, P., Downing, K., Frew, R., Gall, M., Hadfield, M., Hall, J., Harvey, M., Jameson, G., LaRoche, J., Liddicoat, M., Ling, R., Maldonado, M.T., McKay, R.M., Nodder, S., Pickmere, S., Pridmore, R., Rintoul, S., Safi, K., Sutton, P., Strzepek, R. Tanneberger, K., Turner, S., Waite, A., Zeldis, J., 2000. A mesoscale phytoplankton bloom in the polar Southern Ocean stimulated by iron fertilization. Nature 407, 695-702.

Buesseler, K.O., Boyd, P.W., 2003. Will ocean fertilization work? Science 300, 67-68.

Castebrunet, H., Genthon, C., Martinerie, P., 2006. Sulfur cycle at Last Glacial Maximum: model results versus Antarctic ice core data. Geophysical Research Letters 33, L22711. doi:10.1029/2006GL027681.

Castellano, E., Becagli, S., Jouzel, J., Migliori, A., Severi, M., Steffensen, J.P., Traversi, R., Udisti, R., 2003. Volcanic eruption frequency over the last $45 \mathrm{kyr}$ as recorded in Epica-Dome C ice core (East Antarctica) and its relationship with climatic changes. Global and Planetary Change 42, 195-205.

Castellano, E., Becagli, S., Hansson, M., Hutterli, M., Petit, J.R., Rampino, M.R. Severi, M., Steffensen, J.P., Traversi, R., Udisti, R., 2005. Holocene volcanic history as recorded in the sulfate stratigraphy of the European Project for Ice Coring in Antarctica Dome C (EDC96) ice core. Journal of Geophysical Research 110, D06114. doi:10.1029/2004JD005259.

Coale, K.H., Johnson, K.S., Fitzwater, S.E. Gordon, R.M. Tanner, S., Chavez, F.P. Ferioli, L., Sakamoto, C., Rogers, P., Millero, F., Steinberg, P., Nightingale, P.D., Cooper, D., Cochlan, W.P., Landry, M.R., Constantinou, J., Rollwagen, G., Trasvina, A., Kudela, R., 1996. A massive phytoplankton bloom induced by an ecosystem-scale iron fertilization experiment in the equatorial Pacific Ocean. Nature 383, 495-501.

Cosme, E., Hourdin, F., Genthon, C., Martinerie, P., 2005. Origin of dimethylsulfide, non-sea-salt sulfate, and methanesulfonic acid in eastern Antarctica. Journal of Geophysical Research-Atmospheres 110, D03302.

Curran, M.A.J., Jones, G.B., 2000. Dimethyl sulfide in the Southern Ocean: seasonality and flux. Journal of Geophysical Research-Atmospheres 105, 20451-20459.

Curran, M.A.J., van Ommen, T.D., Morgan, V.I., Phillips, K.L., Palmer, A.S., 2003. Ice core evidence for Antarctic sea ice decline since the 1950s. Science 302, 1203-1206.

Davis, D., Chen, G., Kasibhatla, P., Jefferson, A., Tanner, D., Eisele, F., Lenschow, D., Neff, W., Berresheim, H., 1998. DMS oxidation in the Antarctic marine boundary layer: Comparison of model simulations and field observations of DMS, DMSO, DMSO2, H2SO4(g), MSA(g), and MSA(p). Journal of Geophysical ResearchAtmospheres 103, 1657-1678.

Edwards, R., Sedwick, P., 2001. Iron in East Antarctic snow: implications for atmospheric iron deposition and algal production in Antarctic waters. Geophysical Research Letters 28, 3907-3910.

EPICA community members, 2004. Eight glacial cycles from an Antarctic ice core. Nature 429, 623-628.

EPICA community members, 2006. One-to-one coupling of glacial climate variability in Greenland and Antarctica. Nature 444, 195-198.

Fischer, H., Fundel, F., Ruth, U., Twarloh, B., Wegner, A., Udisti, R., Becagli, S., Castellano, E., Morganti, A., Severi, M., Wolff, E., Littot, G., Röthlisberger, R. Mulvaney, R., Hutterli, M.A., Kaufmann, P., Federer, U., Lambert, F., Bigler, M., Hansson, M., Jonsell, U., de Angelis, M., Boutron, C., Siggaard-Andersen, M.L., Steffensen, J.P., Barbante, C., Gaspari, V., Gabrielli, P., Wagenbach, D., 2007a. Reconstruction of millennial changes in dust emission, transport and regional sea ice coverage using the deep EPICA ice cores from the Atlantic and Indian Ocean sector of Antarctica. Earth and Planetary Science Letters 260, 340-354.

Fischer, H., Siggaard-Andersen, M.L., Ruth, U., Röthlisberger, R., Wolff, E., 2007b. Glacial/interglacial changes in mineral dust and sea-salt records in polar ice cores: sources, transport, and deposition. Reviews of Geophysics 45, RG1002. doi:10.1029/2005RG000192.
Fischer, H., Schmitt, J., Lüthi, D., Stocker, T.F., Tschumi, T., Parekh, P., Joss, F., Köhler, P., Völker, C., Gersonde, R., Barbante, C., Le Floch, M., Raynaud, D., Wolff, E., 2010. The role of Southern Ocean processes in orbital and millennial $\mathrm{CO}_{2}$ variations - A synthesis. Quaternary Science Reviews 29, 193-205.

Francois, R., Altabet, M.A., Yu, E.-F., Sigman, D.M., Bacon, M.P., Frank, M. Bohrmannn, G., Bareille, G., Labeyrie, L.D., 1997. Contribution of southern ocean surface-water stratification to low atmospheric $\mathrm{CO}_{2}$ concentrations during the last glacial period. Nature 389, 929-935.

Fuhrer, K., Legrand, M., 1997. Continental biogenic species in the Greenland Ice Core Project ice core: tracing back the biomass history of the North American continent. Journal of Geophysical Research 102, 26,735-26,745.

Galloway, J.N., Dentener, F.J., Capone, D.G., Boyer, E.W., Howarth, R.W., Seitzinger, S.P., Asner, G.P., Cleveland, C.C., Green, P.A., Holland, E.A., Karl, D.M. Michaels, A.F., Porter, J.H., Townsend, A.R., Vorosmarty, C.J., 2004. Nitrogen cycles: past, present, and future. Biogeochemistry 70, 153-226.

Gaspari, V., Barbante, C., Cozzi, G., Cescon, P., Boutron, C.F., Gabrielli, P. Capodaglio, G., Ferrari, C., Petit, J.R., Delmonte, B., 2006. Atmospheric iron fluxes over the last deglaciation: climatic implications. Geophysical Research Letters 33, L03704. doi:10.1029/2005GL024352.

Gersonde, R., Crosta, X., Abelmann, A., Armand, L., 2005. Sea-surface temperature and sea ice distribution of the Southern Ocean at the EPILOG Last Glacia Maximum - a circum-Antarctic view based on siliceous microfossil records. Quaternary Science Review 24, 869-896.

Göktas, F., Fischer, H., Oerter, H., Weller, R., Sommer, S., Miller, H., 2002. A glaciochemical characterization of the new EPICA deep-drilling site on Amundsenisen, Dronning Maud Land, Antarctica. Annals of Glaciology 35, 347-354.

Huybrechts, P., Rybak, O., Pattyn, F., Ruth, U., Steinhage, D., 2007. Ice thinning, upstream advection, and non-climatic biases for the upper $89 \%$ of the EDML ice core from a nested model of the Antarctic ice sheet. Climate of the Past 3 577-589.

Iizuka, Y., Hondoh, T., Fujii, Y., 2008. Antarctic sea ice extent during the Holocene reconstructed from inland ice core evidence. Journal of Geophysical Research 113, D15114. doi:10.1029/2007JD009326.

Johnson, M.T., Bell, T.G., 2008. Coupling between dimethylsulfide emissions and the ocean-atmosphere exchange of ammonia. Environmental Chemistry 5 259-267.

Johnson, M., Sanders, R., Avgoustidi, V., Lucas, M., Brown, L., Hansell, D., Moore, M. Gibb, S., Liss, P., Jickells, T., 2007. Ammonium accumulation during a silicatelimited diatom bloom indicates the potential for ammonia emission events. Marine Chemistry 106, 63-75.

Kaufmann, P.R. Federer, U, Hutterli, M.A., Bigler, M., Schüpbach, S, Ruth, U, Schmitt, J., Stocker, T.F., 2008. An improved continuous flow analysis system for high-resolution field measurements on ice cores. Environmental Science \& Technology 42, 8044-8050.

Kohfeld, K.E., Le Quere, C., Harrison, S.P., Anderson, R.F., 2005. Role of marine biology in glacial-interglacial $\mathrm{CO}_{2}$ cycles. Science 308, 74-78.

Köhler, P., Fischer, H., Munhoven, G., Zeebe, R.E., 2005. Quantitative interpretation of atmospheric carbon records over the last glacial termination. Global Biogeochem Cycles 19, GB4020. doi:10.1029/2004GB002345.

Krinner, G., Genthon, C., 2003. Tropospheric transport of continental tracers towards Antarctica under varying climatic conditions. Tellus B 55, 54-70.

Lambert, F., Delmonte, B., Petit, J.R., Bigler, M., Kaufmann, P.R., Hutterli, M.A., Stocker, T.F., Ruth, U., Steffensen, J.P., Maggi, V., 2008. Dust-climate couplings over the past 800,000 years from the EPICA Dome C ice core. Nature 452, 616.

Legrand, M., Pasteur, E.C., 1998. Methane sulfonic acid to non-sea-salt sulfate ratio in coastal Antarctic aerosol and surface snow. Journal of Geophysical Research 103, 10991-11006.

Legrand, M., Feniet-Saigne, C., Saltzman, E.S., Germain, C., Barkov, N.I., Petrov, V.N 1991. Ice-core record of oceanic emissions of dimethylsulphide during the last climate cycle. Nature 350, 144-146.

Legrand, M., Ducroz, F., Wagenbach, D., Mulvaney, R., Hall, J., 1998. Ammonium in coastal Antarctic aerosol and snow: role of polar ocean and penguin emissions. Journal of Geophysical Research-Atmospheres 103, 11043-11056.

Legrand, M., Wolff, E., Wagenbach, D., 1999. Antarctic aerosol and snowfall chemistry: implications for deep Antarctic ice-core chemistry. Annals of Glaciology 29, 66-72.

Littot, G.C., Mulvaney, R., Röthlisberger, R., Udisti, R., Wolff, E.W., Castellano, E., de Angelis, M. Hansson, M.E., Sommer, S., Steffenssen, J.P., 2002. Comparison of analytical methods used for measuring major ions in the EPICA Dome $C$ (Antarctica) ice core. Annals of Glaciology 35, 299-305.

Lunt, D.J., Valdes, P.J., 2001. Dust transport to Dome C, Antarctica, at the Last Glacial Maximum and present day. Geophysical Research Letters 28, 295-298.

Martin, J.H., Gordon, R.M., Fitzwater, S., Broenkow, W.W., 1989. VERTEX: Phytoplankton/iron studies in the Gulf of Alaska. Deep-Sea Res (I. Oceanogr Res Pap) 36, 649-680.

Martin, J.H., Gordon, R.M., Fitzwater, S.E., 1990. Iron in Antarctic waters. Nature 345 156-158.

Martínez-Garcia, A., Rosell-Melé, A., Geibert, W., Gersonde, R., Masqué, P. Gaspari, V., Barbante, C., 2009. Links between iron supply, marine productivity, sea surface temperature, and $\mathrm{CO} 2$ over the last 1.1 Ma. Paleoceanography 24 PA1207. doi:10.1029/2008PA001657.

Menviel, L., Timmermann, A., Mouchet, A., Timm, O., 2008. Climate and marine carbon cycle response to changes in the strength of the Southern Hemispheric westerlies. Paleoceanography 23, PA4201. doi:10.1029/2008PA0016. 
Minikin, A., Wagenbach, D., Graf, W., Kipfstuhl, J., 1994. Spatial and seasonal variations of the snow chemistry at the central Filchner-Ronne ice shelf, Antarctica. Annals of Glaciology 20, 283-290.

Minikin, A., Legrand, M., Hall, J., Wagenbach, D., Kleefeld, C., Wolff, E.W., Pasteur, E., Ducroz, F., 1998. Sulfur-containing species (sulfate and methanesulfonate) in coastal Antarctic aerosol and precipitation. Journal of Geophysical Research 103 , 10975-10990.

Norman, M., Leck, C., 2005. Distribution of marine boundary layer ammonia over the Atlantic and Indian Oceans during the Aerosols99 cruise. Journal of Geophysical Research-Atmospheres 110, D16302. doi:10.1029/2005JD005866.

Norman, M., Leck, C., Rodhe, H., 2003. Differences across the ITCZ in the chemical characteristics of the Indian Ocean MBL aerosol during INDOEX. Atmospheric Chemistry and Physics 3, 563-579.

O’Dowd, C.D., Lowe, J.A., Smith, M.H., Davison, B., Hewitt, N., Harrison, R.M., 1997. Biogenic sulphur emissions and inferred non-sea-salt-sulphate cloud condensation nuclei in and around Antarctica. Journal of Geophysical ResearchAtmospheres 102, 12839-12854.

Ooki, A., Uematsu, M., Noriki, S., 2007. Size-resolved sulfate and ammonium measurements in marine boundary layer over the North and South Pacific. Atmospheric Environment 41, 81-91.

Parekh, P., Joos, F., Müller, S.A., 2008. A modeling assessment of the interplay between aeolian iron fluxes and iron-binding ligands in controlling carbon dioxide fluctuations during Antarctic warm events. Paleoceanography 23, PA4202. doi:10.1029/2007PA001531.

Parrenin, F., Barnola, J.M., Beer, J., Blunier, T., Castellano, E., Chappellaz, J. Dreyfus, G., Fischer, H., Fujita, S., Jouzel, J., Kawamura, K., Lemieux-Dudon, B. Loulergue, L., Masson-Delmotte, V., Narcisi, B., Petit, J.R., Raisbeck, G. Raynaud, D., Ruth, U., Schwander, J., Severi, M., Spahni, R., Steffensen, J.P., Svensson, A., Udisti, R., Waelbroeck, C., Wolff, E., 2007. The EDC3 chronology for the EPICA dome $C$ ice core. Climate of the Past 3, 485-497.

Piel, C., Weller, R., Huke, M., Wagenbach, D., 2006. Atmospheric methane sulfonate and non-sea-salt sulfate records at the European Project for Ice Coring in Antarctica (EPICA) deep-drilling site in Dronning Maud Land, Antarctica. Journal of Geophysical Research-Atmospheres 111, D03304. doi:10.1029/ 2005JD006213.

Preunkert, S., Legrand, M., Jourdain, B., Moulin, C., Belviso, S., Kasamatsu, N. Fukuchi, M., Hirawake, T., 2007. Interannual variability of dimethylsulfide in air and seawater and its atmospheric oxidation by-products (methanesulfonate and sulfate) at Dumont d'Urville, coastal Antarctica (1999-2003). Journal of Geophysical Research-Atmospheres 112, D06306. doi:10.1029/2006JD007585.

Preunkert, S., Jourdain, B., Legrand, M., Udisti, R., Becagli, S., Cerri, O., 2008. Seasonality of sulfur species (dimethyl sulfide, sulfate, and methanesulfonate) in Antarctica: Inland versus coastal regions. Journal of Geophysical ResearchAtmospheres 113, D15302. doi:10.1029/2008JD009937.

Rankin, A.M., Wolff, E.W., 2000. Ammonium and potassium in snow around an emperor penguin colony. Antarctic Science 12, 154-159.

Rankin, A.M., Wolff, E.W., Martin, S., 2002. Frost flowers; implications for tropospheric chemistry and ice core interpretation. Journal of Geophysical Research 107 (D23), 4683.

Reader, M.C., Fung, I., McFarlane, N., 1999. The mineral dust aerosol cycle during the Last Glacial Maximum. Journal of Geophysical Research-Atmospheres 104 , 9381-9398.

Reijmer, C.H., Van den Broeke, M.R., 2001. Moisture source of precipitation in Western Dronning Maud Land, Antarctica. Antarctic Science 13, 210-220.

Reijmer, H., van den Broeke, R., Scheele, M.P., 2002. Air parcel trajectories and snowfall related to five deep drilling locations in Antarctica based on the ERA15 dataset. Journal of Climate 15, 1957-1968.

Ridgwell, A.J., 2003. Implications of the glacial CO2 "iron hypothesis" for Quaternary climate change. Geochemistry, Geophysics, and Geosystems 4, 1076.

Ridgwell, A.J., Watson, A.J., 2002. Feedback between aeolian dust, climate, and atmospheric CO2 in glacial time. Paleoceanography 17, 1059.

Riseman, S.F., DiTullio, G.R., 2004. Particulate dimethyl-sulfoniopropionate and dimethylsulfoxide in relation to iron availability and algal community structure in the Peru Upwelling System. Canadian Journal of Fisheries and Aquatic Sciences $61,721-735$.
Röthlisberger, R., Bigler, M., Hutterli, M., Sommer, S., Stauffer, B., Junghans, H.G., Wagenbach, D., 2000. Technique for continuous high-resolution analysis of trace substances in firn and ice cores. Environmental Science \& Technology 34 338-342.

Röthlisberger, R., Bigler, M., Wolff, E.W., Joos, F., Monnin, E., Hutterli, M.A., 2004. Ice core evidence for the extent of past atmospheric CO2 change due to iron fertilisation. Geophysical Research Letters 31, L16207.

Ruth, U., Barnola, J.M., Beer, J., Bigler, M., Blunier, T., Castellano, E., Fischer, H., Fundel, F., Huybrechts, P., Kaufmann, P., Kipfstuhl, S., Lambrecht, A., Morganti, A., Oerter, H., Parrenin, F., Rybak, O., Severi, M., Udisti, R., Wilhelms, F., Wolff, E., 2007. EDML1: a chronology for the EPICA deep ice core from Dronning Maud Land, Antarctica, over the last 150000 years. Climate of the Past 3, 475-484.

Sedwick, P.N., DiTullio, G.R., 1997. Regulation of algal blooms in Antarctic shelf waters by the release of iron from melting sea ice. Geophysical Research Letters $24,2515-2518$.

Siegenthaler, U., Stocker, T.F., Monnin, E., Lüthi, D., Schwander, J., Stauffer, B. Raynaud, D., Barnola, J.M., Fischer, H., Masson-Delmotte, V., Jouzel, J., 2005. Stable carbon cycle-climate relationship during the late Pleistocene. Science 310, 1313-1317.

Silvente, E., Legrand, M., 1993. Ammonium to sulfate ratio in aerosol and snow of Greenland and Antarctic regions. Geophysical Research Letters 20, 687-690.

Simo, R., Pedros-Alio, C., 1999. Role of vertical mixing in controlling the oceanic production of dimethyl sulphide. Nature 402, 396-399.

Smetacek, V., 1998. Diatoms and the silicate factor. Nature 391, 224-225.

Sommer, S., Wagenbach, D., Mulvaney, R., Fischer, H., 2000. Glacio-chemical study spanning the past $2 \mathrm{kyr}$ on three ice cores from Dronning Maud Land Antarctica 2. Seasonally resolved chemical records. Journal of Geophysical Research-Atmospheres 105, 29423-29433.

Traufetter, F., Oerter, H., Fischer, H., Weller, R., Miller, H., 2004. Spatio-temporal variability in volcanic sulphate deposition over the past $2 \mathrm{kyr}$ in snow pits and firn cores from Amundsenisen, Antarctica. Journal of Glaciology 50 , 137-146.

Tsigaridis, K., Krol, M., Dentener, F.J., Balkanski, Y., Lathiere, J., Metzger, S., Hauglustaine, D.A., Kanakidou, M., 2006. Change in global aerosol composition since preindustrial times. Atmospheric Chemistry and Physics 6, 5143-5162.

Virkkula, A., Teinila, K., Hillamo, R., Kerminen, V.M., Saarikoski, S., Aurela, M., Viidanoja, J., Paatero, J., Koponen, I.K., Kulmala, M., 2006. Chemical composition of boundary layer aerosol over the Atlantic Ocean and at an Antarctic site. Atmospheric Chemistry and Physics 6, 3407-3421.

Wagenbach, D., Preunkert, S., Schafer, J., Jung, W., Tomadin, L., 1996. Northward transport of Saharan dust recorded in a deep Alpine ice core. Impact of Desert Dust Across The Mediterranean 11, 291-300.

Wagenbach, D., Keck, L., Minikin, A., Ducroz, F., Legrand, M., Hall, J.S., Wolff, E.W., 1998. Sea-salt aerosol in coastal Antarctic regions. Journal of Geophysical Research 103, 10961-10974.

Watson, A.J., Bakker, D.C.E., Ridgwell, A.J., Boyd, P.W., Law, C.S., 2000. Effect of iron supply on Southern Ocean CO2 uptake and implications for glacial atmospheric CO2. Nature 407, 730-733.

Weller, R., Wagenbach, D., 2007. Year-round chemical aerosol records in continental Antarctica obtained by automatic samplings. Tellus Series B-Chemical and Physical Meteorology 59, 755-765.

Weller, R., Traufetter, F., Fischer, H., Oerter, H., Piel, C., Miller, H., 2004. Postdepositional losses of methane sulfonate, nitrate, and chloride at the European Project for Ice Coring in Antarctica deep-drilling site in Dronning Maud Land, Antarctica. Journal of Geophysical Research-Atmospheres 109, D07301.

Wolff, E.W., Fischer, H., Fundel, F., Ruth, U., Twarloh, B., Littot, G.C., Mulvaney, R., Rothlisberger, R., de Angelis, M., Boutron, C.F., Hansson, M., Jonsell, U., Hutterli, M.A., Lambert, F., Kaufmann, P., Stauffer, B., Stocker, T.F., Steffensen, J.P., Bigler, M., Siggaard-Andersen, M.L., Udisti, R., Becagli, S., Castellano, E., Severi, M., Wagenbach, D., Barbante, C., Gabrielli, P., Gaspari, V., 2006. Southern Ocean sea-ice extent, productivity and iron flux over the past eight glacial cycles. Nature 440, 491-496.

Yang, X., Pyle, J.A., Cox, R.A., 2008. Sea salt aerosol production and bromine release: role of snow on sea ice. Geophysical Research Letters 35, L16815. 